\title{
UPAYA PENINGKATAN PEMBELAJARAN BAHASA ARAB DENGAN PENERAPAN MANAJEMEN BERBASIS SEKOLAH (MBS).
}

\author{
Oleh : Taufik Nur
}

Penelitian ini bertujuan: Mendeskripsikan pelaksanaan kegiatan peningkatan pembelajaran bahasa arab di Madrasah Tsanawiyah Negeri 3 Sinjai Tengah Kabupaten Sinjai. Mengetahui kemampuan peserta didik di Madrasah Tsanawiyah Negeri 3 Sinjai Tengah Kabupaten Sinjai. Mengungkapkan permasalahan-permasalahn apa saja yang menjadi permasalahn dalam kegiatan upaya peningkatan pembelajaran dengan penerapan manajemen berbasis sekolah di Madrasah Tsanawiyah Negeri 3 Sinjai Tengah Kabupaten Sinjai. Penelitian ini adalah penelitian lapangan (field research) yang bersifat kualitatif deskriptif, dengan menggunakan pendekatan yang dianggap relevan dengan variabel utama yang diteliti, yakni pendekatan linguistik, pedagogis, dan pendekatan manajerial. Adapun informan yang dijadikan sebagai narasumber adalah kepala madrasah, wakil kepala madrasah, guru-guru bidang studi, staf tata usaha, pembina ekstrakurikuler, pengurus komite, orang tua peserta didik, masyarakat, dan peserta didik itu sendiri. Metode pengumpulan data yang digunakan adalah observasi, dokumentasi dan wawancara. Teknik analisis data berupa triangulasi berbagai sumber, berbagai cara dan berbagai waktu. Hasil penelitian tesis ini memberikan gambaran tentang bagaimana proses pembelajaran bahasa arab di MTs.N 3 Sinjai Tengah Kabupaten Sinjai. Serta mengungkapkan langkah-langkah yang dilakukan dalam meningkatkan pembelajaran bahasa arab dengan penerapan manajemen berbasis sekolah. Dan menguraikan faktor-faktor yang dapat mendukung dan menghambat peningkatan pembelajaran bahasa arab di MTs.N 3 Sinjai Tengah Kabupaten Sinjai.

Kata Kunci: Pembelajaran Bahasa Arab, Manajemen Berbasis Sekolah (MBS)

\section{A. Pendahuluan}

Luasnya Negara Kesatuan Republik Indonesia dan sangat bervariasinya kondisi daerah beserta masalah-masalah yang dihadapi telah mendorong pemerintah untuk lebih memperhatikan potensi daerah dan kendalanya dalam perencanaan. Standarisasi dan penyeragaman rencana yang terlalu terpusat dirasakan menghambat pelaksanaan pembangunan karena cenderung akan berakibat pada ketidaksesuaian antara rencana pusat dan kebutuhan daerah masing-masing.

Pemberdayaan sekolah adalah bukan merupakan pekerjaan yang ringan. Apalagi pemberdayaan sekolah sebagai wahana sosialisasi, maka hal itu harus dapat dilakukan melalui pemberdayaan manajemen sekolah dengan mengembangkan kepemimpinan kepala madrasah yang efektif. Karena hanya dengan kepemimpinan kepala madrasah yang efektif, proses pemberdayaan guru akan berlangsung sesuai dengan iklim sekolah.

Jadi, sekolah sebagai suatu lembaga pendidikan yang ideal seharusnya mampu melakukan proses edukasi, sosialisasi dan transformasi. Dengan kata lain sekolah yang 
bermutu adalah sekolah yang mampu berperan sebagai proses edukasi (proses pendidikan yang menekankan pada kegiatan mendidik dan mengajar), proses sosialisasi (proses bermasyarakat terutama bagi anak didik), dan wadah transformasi (proses perubahan tingkah laku ke arah yang lebih baik atau lebih maju). ${ }^{1}$

Eksistensi manajemen berbasis sekolah di sekolah menjadikan peran penting dalam mengembangkan dan memajukan lembaga pendidikan, tenaga kependidikan, dan outputnya. Menurut Sudarwan Danim, bahwa kepala madrasah memiliki multiperan sebagai adiministrator, manager, leader, chief, motivator, negosiator, figure, communicator, wakil lembaga dalam urusan eksternal dan fungsi-fungsi yang lainnya. ${ }^{2}$ Hal ini sejalan dengan gerakan reformasi di Indonesia yang secara umum menuntut penerapan prinsip demokrasi, desentralisasi, serta menjunjung tinggi hak asasi manusia dalam kehidupan berbangsa dan bernegara. Salah satu perubahan mendasar yang dirasakan dalam dunia pendidikan saat ini adalah adanya sistem manajemen desentralistik, yakni dengan lahirnya UU Nomor 32 Tahun 2004 tentang pemerintahan daerah ${ }^{3}$ yang dikenal dengan istilah dalam manajemen pendidikan, yaitu manajemen berbasis sekolah. Manajemen berbasis sekolah (MBS) muncul sebagai salah satu solusi untuk meningkatkan mutu pendidikan nasional.

Madrasah sebagai satuan pendidikan Islam yang mengemban amanah untuk membentuk watak serta peradaban bangsa yang bermartabat dalam rangka mencerdaskan kehidupan bangsa memiliki ciri khas dan karakteristik tersendiri. Salah satu kekhasan madrasah adalah adanya mata pelajaran bahasa Arab. Oleh karena itu kurikulum bahasa Arab perlu dirumuskan dan dikembangkan, sehingga di satu sisi memiliki relevansi dengan kebutuhan dan perkembangan masyarakat dalam rangka mewujudkan pendidikan nasional. Di sisi lain kurikulum bahasa Arab sedapat mungkin mencerminkan eksistensi dan jati diri madrasah sebagai lembaga pendidikan integral dari sistem pendidikan nasional. ${ }^{4}$

\section{B. Pembelajaran Bahasa Arab}

\section{Pembelajaran Bahasa Arab}

Kata pembelajaran berasal dari kata dasar belajar yang mendapat awalan pe dan akhiran-an. Menurut Muhibbin Syah, belajar mempunyai arti tahapan perubahan seluruh tingkah laku individu yang relatif menetap sebagai hasil pengalaman dan interaksi dengan lingkungan yang melibatkan proses kognitif. ${ }^{5}$

Istilah pembelajaran berdasarkan UU Nomor 20 Tahun 2003 tentang Sistem Pendidikan Nasional Pasal 1 Bab pertama, adalah proses interaksi peserta didik dengan

\footnotetext{
${ }^{1}$ E. Mulyasa, Menjadi Guru Profesional, (Bandung: Rosakarya, Cet. VII, 2008), h. 73.

${ }^{2}$ Sudarwan Danim, Menjadi Komunitas Pembelajaran (Jakarta: Bumi Aksara, 2005), h. 77

${ }^{3}$ Pemerintah Republik Indonesia, Undang-Undang Dasar Negara RI Tahun 1945, pasal 31 ayat (4)

${ }^{4}$ Kementerian Agama RI, Pedoman Khusus Bahasa Arab Madrasah Tsanawiyah, (Jakarta: Dirjen Kelembagaan Agama Islam Depag RI, 2004), h. iii.

${ }_{5}^{5}$ Muhibbin Syah, Psikologi Pendidikan, (Bandung: PT. Remaja Rosdakarya, 2000), h. 92
} 
pendidik dan sumber belajar pada suatu lingkungan belajar. ${ }^{6}$ Jadi interaksi peserta didik dengan guru atau sumber belajar yang lain dalam lingkungan belajar disebut pembelajaran.

Surya, sebagaimana dikutip oleh Abdul Majid, berpendapat bahwa pembelajaran adalah suatu proses yang dilakukan individu untuk memperoleh suatu perubahan perilaku, sebagai hasil dari pengalaman individu dalam berinteraksi dengan lingkungannya. Senada dengan itu, E. Mulyasa mengemukakan bahwa pembelajaran merupakan aktualisasi kurikulum yang menuntut keaktifan guru dalam menciptakan dan menumbuhkan kegiatan peserta didik sesuai dengan rencana yang telah diprogramkan. ${ }^{7}$

Adapun pembelajaran bahasa Arab merupakan sesuatu yang dapat mengembangkan keterampilan berkomunikasi lisan dan tulisan serta memahami dan mengungkapkan informasi, ide, perasaan, mengembangkan ilmu pengetahuan, teknologi dan budaya. Lingkungan adalah salah satu unsur dan faktor baik secara materi maupun non materi mempunyai pengaruh dalam proses pembelajaran bahasa Arab dan peserta didik mampu meningkatkan kemahiran berbahasa Arab, mendorong dan memberanikan mereka untuk mempraktekkannya dalam kehidupan sehari-hari, atau segala sesuatu yang didengar dan dilihat dari sesuatu yang mempengaruhi mereka adalah pembelajaran bahasa Arab.

Dengan demikian dapat disimpulkan bahwa pembelajaran (proses belajar mengajar) adalah suatu aktifitas (upaya) seorang pendidik yang disengaja untuk memodifikasi (mengorganisasikan) berbagai komponen belajar mengajar yang diarahkan tercapainya tujuan yang ditentukan. Dari istilah proses belajar dan mengajar terdapat hubungan yang sangat erat. Bahkan terjadi kaitan dan interaksi saling pengaruh-mempengaruhi dan saling menunjang satu sama yang lain adapun tujuan belajar merupakan kriteria mencapai derajat mutu dan efisiensi pembelajaran itu sendiri. Perbuatan belajar adalah proses yang komplek.

Beberapa unsur yang terkait dalam proses pembelajaran terdiri dari:

\section{a. Motivasi belajar peserta didik}

Dalam pembelajaran harus ada upaya-upaya agar motivasi yang sudah ada pada diri pembelajaran tetap terpelihara dan ditingkatkan karena motivasi berguna untuk menghubungkan pengalaman yang lama dengan bahan pelajaran yang baru, sebab setiap peserta didik datang ke kelas dengan latar belakang yang berbeda-beda. Dengan motivasi, peserta didik mengalami dalam belajar dan merasa terdorong untuk mempelajari bahan-bahan baru.

\section{b. Bahan ajar}

Bahan belajar yang tersedia harus mendukung bagi pencapaian tujuan belajar peserta didik karena itu penggunaan bahan belajar harus selektif dan disesuaikan dengan komponenkomponen lainnya.

\footnotetext{
${ }^{6}$ Pemerintah Republik Indonesia, Undang-Undang Sistem Pendidikan Nasional, No. 20 Tahun 2003, (Jakarta : Sinar Grafika, 2009), h. 5

${ }^{7}$ E. Mulyasa, Manajemen Pendidikan Karakter, (Jakarta: Bumi Aksara, 2012), h. 129
} 
c. Alat bantu ajar

Suasana belajar perlu dikembangkan agar masing-masing peserta didik biasa kompetitif. Sebab dengan kompetitif yang sehat akan memungkinkan setiap peserta didik dapat berprestasi secara maksimal dan dapat mencapai prestasi yang setinggi mungkin.

\section{d. Suasana belajar}

Suasana belajar penting artinya bagi kegiatan belajar. Suasana yang menyenangkan dapat menumbuhkan kegairahan belajar, sedangkan suasana yang kacau, ramai, tak tenang dan banyak gangguan, sudah tentu tidak menunjang kegiatan belajar yang efektif. Karena itu, guru dan peserta didik senantiasa dituntut agar menciptakan suasana lingkungan belajar yang baik dan menyenangkan, menantang dan menggairahkan. Hal ini berarti bahwa suasana belajar turut menentukan motivasi, kegiatan, keberhasilan belajar peserta didik.

e. Kondisi subyek yang belajar

Kondisi subyek dapat dibedakan atas kondisi fisik ataupun psikis, kondisi fisik meliputi ukuran tubuh, kekuatan tubuhnya, kesehatannya, aspirasinya dan harapannya oleh karena itu kondisi peserta didik perlu diperhatikan. Dari kelima unsur inilah yang bersifat dinamis itu, yang sering berubah, menguat atau melemah dan yang mempengaruhi proses belajar tersebut. ${ }^{8}$

Unsur-unsur dinamis pada guru meliputi:

a. Motivasi membelajarkan Peserta didik

Guru harus memiliki motivasi untuk membelajarkan peserta didik. Motivasi itu timbul dari kesadaran yang tinggi untuk mendidik para peserta didik agar lebih baik, jadi guru harus memiliki hasrat untuk menyiapkan peserta didik menjadi pribadi yang memiliki pengetahuan dan kemampuan.

\section{b. Kondisi Guru Siap Membelajarkan Peserta didik}

Guru perlu memiliki kemampuan dalam proses pengajaran selain kemampuan dalam proses pengajaran, kemampuan kepribadian dan kemampuan kemasyarakatan. Maka guru perlu berupaya meningkatkan kemampuannya agar senantiasa berada dalam kondisi siap membelajarkan peserta didik. ${ }^{9}$

2. Karakteristik Pembelajaran Bahasa Arab

Secara etimologi, karakteristik berasal dari akar kata bahasa Inggris yaitu character yang berarti watak, sifat, ciri. ${ }^{10}$ Kata characteristic berarti sifat yang khas

${ }^{8}$ Oemar Hamalik, Kurikulum dan Pembelajaran, h. 50.

${ }^{9}$ E. Mulyasa, Menjadi Guru Profesional Menciptakan Pembelajaran Kreatif dan Menyenangkan (Bandung: PT Rosda Karya, 2008), h. 51.

${ }^{10}$ John M.Echols dan Hassan Shadily, Kamus Inggris Indonesia (Jakarta: PT. Gramedia, 2006), h. 107. 
atau ciri khas sesuatu ${ }^{11}$. Achmad Maulana mengartikan karakteristik dengan ciri khas, bentuk-bentuk watak dan tabiat individu, corak tingkah laku atau tanda khusus.

Dalam istilah bahasa Arab, kata karakteristik dikenal dengan خصائص sebagai bentuk jamak dari خصوصيـ yang diartikan dengan kekhususan atau keistimewaan. Maka dapat dikatakan bahwa karakteristik bahasa Arab adalah bentuk watak dan ciri khas atau tandatanda khusus yang dimiliki bahasa Arab. ${ }^{12}$

Pengetahuan tentang karakteristik bahasa Arab merupakan tuntutan yang harus dipahami oleh para tenaga pendidik bahasa Arab, karena pemahaman akan diskursus ini akan memudahkan mereka yang berkecimpung pada bidang pendidikan dan pembelaran bahasa Arab dalam melaksanakan kegiatan proses pembelajaran. berikut:

Adapun karakteristik universalitas bahasa Arab antara lain dapat diuraikan sebagai

1) Bahasa Arab memiliki gaya bahasa yang beragam, yang meliputi: a) ragam sosial atau sosiolek yaitu ragam bahasa yang menunjukan stratifikasi sosial ekonomi penuturnya, b) ragam geografis, ragam bahasa yang menunjukan letak geografis penutur antara satu daerah dengan daerah lain, sehingga melahirkan dialek yang beragam, c) ragam idiolek yaitu ragam bahasa yang menunjukan integritas kepribadian setiap individu masyarakat (لهجة فردية).

2) Bahasa Arab dapat diekspresikan secara lisan atau pun tulisan. Menurut Bloomfield bahasa lisan merupakan hakekat adanya suatu bahasa. Realitas ini dapat dipahami karena adanya bentang sejarah peradaban manusia, terlihat jelas mereka pada umumnya berbahasa lisan meskipun diantara mereka tidak dapat menulis dan tidak mengenal lambang tulisan. Bahasa lisan sebagai sistem verbal lebih banyak dipakai oleh manusia dalam berkomunikasi antara satu dengan lainnya antar anggota masyarakat di lingkungannya. Hal ini dimaksudkan agar penyampaian pesan lebih cepat dipahami maknanya oleh masyarakat sasaran.

\section{Tujuan Pembelajaran Bahasa Arab}

Mata pelajaran bahasa Arab merupakan suatu mata pelajaran yang diarahkan untuk mendorong, membimbing, mengembangkan dan membina kemampuan serta menumbuhkan sikap positif terhadap bahasa Arab baik Reseptif maupun Produktif. Kemampuan Resertif yaitu kemampuan untuk memahami pembicaraan orang lain dan memahami bacaan. Kemampuan Produktif yaitu kemampuan menggunakan bahasa sebagai alat komunikasi baik secara lisan maupun tulis. Kemampuan berbahasa Arab serta sikap positif terhadap bahasa Arab tersebut sangat penting dalam membantu memahami sumber ajaran islam yaitu AlQur'an dan Hadits, serta kitab-kitab bahasa Arab yang berkenaan dengan islam bagi peserta didik.

Untuk itu bahasa Arab di Madrasah dipersiapkan untuk pencapaian kompetensi dasar berbahasa, yang mencakup empat keterampilan berbahasa yang diajarkan secara integral, yaitu menyimak, berbicra, membaca dan menulis. Meskipun begitu, pada tingkat pendidikan

\footnotetext{
${ }^{11}$ John M.Echols dan Hassan Shadily, Kamus Inggris Indonesia, h. 108

${ }^{12}$ Ahmad Maulana, dkk., Kamus Ilmiah Populer (Yogyakarta: Absolut, 2004), h. 202.
} 
dasar (Elementary) dititik beratkan pada kecakapan menyimak dan berbicara sebagai landasan berbahasa. Pada tingkat pendidikan menengah (Intermediate), keempat kecakapan berbahsa diajarkan secara seimbang.

Adapun pada tingkat pendidikan lanjut (Advanced) dikonsentrasikan pada kecakapan membaca dan menulis, sehingga peserta didik diharapkan mampu mengakses berbagai referensi bahasa Arab.

Mata pelajaran bahasa Arab memiliki tujuan sebagai berikut:

a. Mengembangkan kemampuan berkomunikasi dalam bahasa Arab, baik lisan maupun tulis, yang mencakup empat kecakapan berbahasa, yakni menyimak (Istima'), berbicara (Qira'ah), dan menulis (Kitabah).

b. Menumbuhkan kesadaran tentang pentingnya bahasa Arab sebagai salah satu bahasa asing untuk menjadi alat utama belajar, khususnya dalam mengkaji sumber-sumber ajaran islam.

c. Mengembangkan pemahaman tentang saling keterkaitan antara bahasa dan budaya serta memperluas cakrawala budaya dan melibatkan diri dalam keragaman budaya. ${ }^{13}$

Ruang lingkup pembelajaran bahasa Arab meliputi tema-tema tentang perkenalan, peralatan madrasah, pekerjaan, alamat, keluarga, anggota badan, dirumah, dikebun, di madrasah, di laboratorium, di perpustakaan, di kantin, jam, kegiatan sehari-hari, pekerjaan, rumah, dan rekreasi.

Tercapainya suatu keberhasilan dalam keterampilan berbahasa Arab ditandai beberapa kemahiran diantaranya:

a). Kemahiran menyimak (istima')

Kemahiran menyimak (listening) skill dapat dicapai dengan latihanlatihanmendengar perbedaan satu phoneme dengan phoneme yang lainnya antara satu ungkapan dengan ungkapan lainnya, baik langsung dari native speaker atau melalui rekaman tape untuk memahami bentuk dan arti dari apa yang didengar diperlukan latihan latihan berupa mendengarkan materi yang direkam dan pada waktu yang bersamaan melihat rangkaian gambar yang mencerminkan arti dari isi apa yang didengarkan tersebut.

b). Kemahiran berbicara (kalam)

Kemahiran berbicara atau speaking skill merupakan kemahiran linguistic yang paling rumit, karena ini menyangkut masalah berfikir atau memikirkan apa yang harus dikatakan sementara menyatakan apa yang telah dipikirkan. Semua ini memerlukan persediaan kata dan kalimat tertentu yang cocok dengan situasi yang dikehendaki dan memerlukan banyak latihan ucapan dan ekspresi atau menyatakan pikiran dan perasaan secara lisan system leksikal, gramatikal dan semantic digunakan simultan dengan intonasi tertentu.

\footnotetext{
${ }^{13}$ Peraturan Menteri Agama No. 2 Tahun 2008, Bab VI.
} 


\section{c). Kemahiran membaca (Qiro'ah)}

Kemahiran membaca mencakup dua hal yaitu mengenali simbul-simbul tertulis dan memahami isinya dengan beberapa cara. Diantaranya dengan membekali murid dengan perbendaharaan kata yang cukup. Aktifitas membaca, menyediakan input bahasa sama seperti menyimak.

Namun demikian membaca memiliki kelebihan dari menyimak dalam hal pemberian butir linguistic yang lebih akurat. Disamping itu pembaca yang baik bersifat otonom dan bisa berhubungan dengan melalui majalah, buku atau surat kabar berbahasa Arab dengan cara seperti itu pembelajaran akan memperoleh kosakata dan bentuk-bentuk bahasa dalam jumlah banyak yang sangat bermanfaat dalam interaksi komunikatif, faktor tersebut jelas menunjukkan bahwa pengajaran membaca perlu memperoleh perhatian serius dan wacana membaca tidak boleh hanya dipandang sebagai batu loncatan bagi aktivitas berbicara dan menulis semata, tujuan pengajaran bahasa sebagaimana kita ketahui adalah mengembangkan kemampuan bagi peserta didik, dengan demikian guru bertugas untuk meyakinkan bahwa proses belajar mengajar akan menjadi pengalaman yang sangat menyenangkan bagi para peserta didik.

d). Kemahiran menulis (Kitabah)

Kemahiran menulis menyangkut 3 hal yaitu:

1) Kemahiran membuat alphabet

Kemahiran membuat alphabet dimaksud untuk menyatakan bunyi berbeda-beda antara bahasa yang lain.

2) Kemahiran mengeja

Kemahiran mengeja ini akan berkembang menjadi modifikasi kalimat yaitu mengubah kalimat yang ada dengan unsure yang lain, menyempurnakan kalimat yang belum selesai atau mengubah kalimat aktif menjadi pasif, begitu sebaliknya.

3) Kemahiran menyatakan perasaan dan pikiran melalui tulisan atau yang lazimnya disebut komposisi. Kemahiran ini dapat dicapai melalui latihan-latihan berupa:

(a) Merangkum bacaan terpilih dan menceritakan kembali dalam bentuk tulisan, tetapi menggunakan kata-kata peserta didik itu sendiri.

(b) Menceritakan gambaran yang dilihat atau pekerjaan yang dilakukan peserta didik sehari-hari.

(c) Membuat diskripsi suatu gambaran atau peristiwa sampai masalah sekecil-kecilnya.

(d) Menceritakan perbuatan yang biasanya dilakukan oleh peserta didik, seperti mengendarai sepeda dan lain-lainnya. ${ }^{14}$

\footnotetext{
${ }^{14}$ Furqonul Aziz dan Chaidar Al-Wasilah, Pengajaran Bahasa Komunikatif, (Bandung: Remaja Rosda
} Karya, 2000, Cet. II), 108. 
Pelajaran Bahasa Arab termasuk dalam kurikulum pendidikan agama, karena itu pelajaran bahasa Arab merupakan mata pelajaran yang penting untuk diajarkan. Bahan ajar yang di pakai sesuai dengan KTSP standar isi 2006 Tema-tema yang diajarkan pada pelajaran bahasa Arab tentang perkenalan, peralatan madrasah, pekerjaan, alamat, keluarga, anggota badan, dirumah, dikebun, di madrasah, di laboratorium, di perpustakaan, di kantin, jam, kegiatan sehari-hari, pekerjaan, rumah, dan rekreasi. Dimana tema-tema tersebut berpatokan pada Standar Kompetensi (SK), Kompetensi Dasar (KD) dan Standar Kompetensi Lulusan (SKL) pelajaran bahasa Arab yaitu:

\section{a. Menyimak}

Memahami wacana lisan dalam bentuk paparan atau dialog tentang perkenalan dan hal-hal yang ada di lingkungan rumah maupun sekolah.

\section{b. Berbicara}

Mengungkapkan makna secara lisan dalam bentuk paparan atau dialog tentang perkenalan dan hal-hal yang ada di lingkungan rumah maupun sekolah

c. Membaca

Membaca dan memahami makna wacana tertulis dalam bentuk paparan atau dialog tentang perkenalan dan hal-hal yang ada di lingkungan rumah maupun sekolah

\section{d. Menulis}

Menuliskan kata, ungkapan, dan teks fungsional pendek sederhana dengan ejaan dan tanda baca yang tepat. ${ }^{15}$

\section{Manajemen Berbasis Sekolah (MBS)}

\section{Manajemen Berbasis Sekolah}

Manajemen berbasis sekolah dapat di artikan sebagai suatu proses kerja komunitas sekolah dengan cara menerapkan kaidah kaidah otonomi, akuntabilitas, partisipasi, dan sustainability untuk mencapai tujuan pendidikan dan pembelajaran secara bermutu ${ }^{16}$.

Menurut Judith Capman, MBS adalah "school based management refers to form of education administration in which the school become the primary unit for decision making, it differs from more traditional form of educational administration in which central bureaucracy dominate in the decision making process" (manajemen berbasis sekolah adalah merujuk pada suatu bentuk administrasi pendidikan, dimana sekolah menjadi unit kecil utama

\footnotetext{
${ }^{15}$ Permenag No 2 Tahun 2008, BAB I, Tentang Standar Kompetensi Lulusan Mata Pelajaran Pendidikan Agama Islam dan Bahasa Arab Madrasah Ibtidaiyah. 34

${ }^{16}$ Sudarwan Danim, Visi Baru Manajemen Sekolah, Dari Unit Birokrasi Ke Lembaga Akademik, h. 33-
} 
dalam pengambilan keputusan. Hal ini berbeda dengan bentuk tradisional administrasi pendidikan, yakni pemerintah pusat sangat menonjol dalam pengambilan keputusan). ${ }^{17}$

Ada dua faktor yang menunjang dalam memahami hubungan antara sekolah dan masyarakat, yaitu:

Faktor pertama, tantangan profesionalitas terhadap penyelenggara pendidikan di sekolah untuk memenuhi keinginan/harapan/cita-cita masyarakat. Dalam hal ini, tantangan profesionalitas berkaitan dengan usaha usaha yang dilakukan seorang guru dalam merubah program atau sistem pembelajaran yang memiliki kecenderungan dan kesesuaian terhadap norma-norma yang ada dalam masyarakat. Jika sekolah yang ada tidak memberikan kontribusi yang baik dan konstruktif kepada masyarakat, maka secara reaktif masyarakat akan menolak keberadan sekolah akan sangat didukung dan diharapkan oleh masyarakat di tempat tersebut.

Faktor kedua, tantangan masyarakat terhadap para penyelenggara pendidikan yang syarat dengan tuntutan norma-norma profesionalitas. Tantangan yang dimaksudkan adalah menyangkut masalah-masalah yang disebabkan adanya keinginan antara masyarakat dan sekolah untuk memperbaiki pendidikan. Sekolah secara intensif bersama-sama dengan masyarakat melalui aksi-aksi secara pasti dan mengevaluasi apa yang sedang berlangsung di sekolah. Masyarakat pada umumnya hanya menghendaki hasil yang diperoleh di sekolah dari segi efektifitas, dan dalam banyak kasus pula, masyarakat pada umumnya menghendaki dilibatkan dalam poses penentuan kebijakan sekolah.

Jika dicermati dari penjelasan di atas, MBS dapat diartikan sebagai format pengelolaan pembelajaran yang sesuai dengan kebutuhan peserta didik, sekolah, dan masyarakat. Dengan penjabaran bahwa masing-masing komponen (peserta didik, sekolah dan masyarakat) mempunyai tanggung jawab bersama untuk menciptakan sekolah yang bermutu dan berkesinambungan.

Dengan demikian, MBS yang akan dikembangkan merupakan bentuk alternative sekolah dalam program desentralisasi bidang pendidikan yang ditandai dengan adanya otonomi luas di tingkat sekolah, partsipasi masyarakat yang tinggi tapi masih dalam kerangka kebijakan pendidikan nasional. Tetapi, semua ini harus mengakibatkan peningkatan proses belajar mengajar. Sekolah yang menerapkan prinsip prinsip MBS adalah sekolah yang harus lebih bertanggung jawab (high responbility) kreatif dalam bertindak dan mempunyai wewenang lebih (more authority) serta dapat dituntut pertanggungjawabannya oleh yang berkepentingan (public accountability by stake holders). ${ }^{18}$

\section{Konsep Dasar Manajemen Berbasis Sekolah}

Bukti empirik lemahnya pola lama manajemen pendidikan nasional dan digulirkannya otonomi daerah, maka sebagai konsekuensi logis bagi manajemen pendidikan di Indonesia

\footnotetext{
${ }^{17}$ Jamal Ma'mur Asmani, Tips Aplikasi Manajemen Sekolah, (DIVA press, anggota IKAPI, 2012), h. 33

${ }^{18}$ Kementerian Pendidikan Nasional, Paket Pelatihan 1, peningkatan mutu pendidikan dasar melalui manajemen berbasis sekolah, peran serta masyarakat, pembelajaran aktif, kreatif, efektif dan menyenangkan, Juni 2005
} 
adalah perlu dilakukan penyesuaian diri dari pola lama manajemen pendidikan masa depan yang lebih bernuansa otonomi dan yang lebih demokratis. ${ }^{19}$ Yang menjadi dasar dari MBS adalah otonomi sekolah. MBS dapat didefinisikan sebagai model manajemen yang memberikan otonomi lebih besar kepada sekolah dan mendorong sekolah untuk melakukan pengambilan keputusan secara partisipatif untuk memenuhi kebutuhan mutu sekolah atau untuk mencapai tujuan mutu sekolah dalam rangka pendidikan nasional. Karena itu, esensi MBS: otonomi sekolah dan pengambilan keputusan partisipatif untuk mencapai sasaran mutu sekolah. ${ }^{20}$

Otonomi sekolah menjadi tuntutan logis manakala peningkatan mutu akademik diinginkan, sedangkan otonomi pendidikan menunjuk pada konsekuensi politik, manakala UU No. 2 tahun 1999 tentang otonomi daerah dilaksanakan. Jadi tidak dengan sendirinya otonomi sekolah terjadi ketika otonomi pendidikan ditegaskan secara politis di Kabupaten/Kota. Otonomi pendidikan sebagai keputusan pemerintah daerah dapat membawa serta otonomi sekolah:

a. Keputusan itu serta merta mendorong terbentuk dan berfungsinya komite sekolah di tiap sekolah.

b. Tertuang secara jelas komitmen Pemda untuk meningkatkan partisipasi masyarakat terhadap sekolah-sekolah di wilayahnya.

c. Semua anggota terdorong memiliki rencana pengembangan induk sekolah dan,

d. Terbentuk model-model sekolah yang secara mandiri mampu mengembangkan aspekaspek manajerial kurikulum, kepala madrasah, informasi pendidikan, dan pembinaan profesionalisme guru. ${ }^{21}$

Jadi otonomi sekolah adalah kewenangan sekolah untuk mengatur dan mengurus kepentingan warga sekolah menurut prakarsa sendiri berdasarkan aspirasi warga sekolah sesuai dengan peraturan perundang-undangan pendidikan nasiosnal yang berlaku. ${ }^{22}$

Oleh karena itu, adanya upaya pemerintah pusat menggalakkan MBS harus dipahami dan dua konteks, Pertama, dengan akan diterapkannya MBS di sekolah-sekolah pada dasarnya ke depan akan terjadi peralihan dari pendekatan makro menuju pendekatan mikro, atau peralihan dari pendekatan yang sentralistik menuju district approach dan school autonomy (desentralistik) dalam upaya peningkatan mutu pendidikan. Kedua, walaupun MBS mulai diperkenalkan ke sekolah-sekolah di Indonesia sekitar tahun 1997/1998 namun sebenarnya sekolah-sekolah swasta disadari atau tidak telah lama menerapkannya. Selama ini sekolah swasta berusaha mengelolanya secara mandiri.

\section{Tujuan Manajemen Berbasis Sekolah}

Manajemen Berbasis Sekolah merupakan salah satu upaya pemerintah untuk mencapai keunggulan masyarakat bangsa dalam penguasaan ilmu dan teknologi, yang

\footnotetext{
${ }^{19}$ Umaedi, Managemen Peningkatan Mutu Berbasis Sekolah, (Jakarta: Kementerian Pendidikan Nasional Direktorat Jendral Pendidikan Dasar dan Menengah Direktorat Sekolah Lanjutan Tingkat Pertama, 2001), h. 3

${ }^{20}$ Umaedi, Managemen Peningkatan Mutu Berbasis Sekolah, h. 9

${ }^{21}$ Eddy Warsono dan Karsidi Budi Anggoro, Otonomi Pendidikan di Era Otonomi Daerah, h. 13

${ }^{22}$ Umaedi, Managemen Peningkatan Mutu Berbasis Sekolah, h. 9
} 
dinyatakan dalam GBHN. Hal tersebut diharapkan dapat dijadikan landasan dalam pengembangan pendidikan di Indonesia yang berkualitas dan berkelanjutan, baik secara makro, maupun mikro.

Manajemen berbasis sekolah, yang ditandai dengan otonomi sekolah dan pelibatan masyarakat merupakan respons pemerintah terhadap gejala-gejala yang muncul di masyarakat, bertujuan untuk meningkatkan efisiensi, mutu, dan pemerataan pendidikan. Pendidikan efisiensi, antara lain diperoleh melalui keleluasaan mengelola sumber daya partisipasi masyarakat dan pemberdayaan birokrasi. Sementara peningkatan mutu dapat diperoleh, antara lain, melalui partisipasi orang tua terhadap sekolah, fleksibilitas pengelolaan sekolah dan kelas, peningkatan profesionalisme guru dan kepala madrasah, berlakunya sistem intensif serta disintensif.

Manajemen Berbasis Sekolah bertujuan untuk:

a. Meningkatkan mutu pendidikan melalui kemandirian dan inisiatif sekolah dalam mengelola dan memberdayakan sumber daya yang tersedia.

b. Meningkatkan kepedulian warga sekolah dan masyarakat dalam penyelenggaraan pendidikan melalui pengambilan keputusan bersama.

c. Meningkatkan tanggung jawab sekolah kepada orang tua, masyarakat, dan pemerintah tentang mutu sekolahnya, dan

d. Meningkatkan kompetisi yang sehat antara sekolah tentang mutu pendidikan yang akan dicapai. ${ }^{23}$

Menurut Direktorat Jendral Pendidikan Dasar dan Menengah (2000) MBS bertujuan untuk memandirikan atau memberdayakan sekolah melalui pemberian wewenang, keluwesan, dan sumber daya untuk meningkatkan mutu sekolah. Dengan kemandiriannya, diharapkan:

a. Sekolah sebagai lembaga pendidikan yang lebih mengetahui kekuatan, kelemahan, peluang dan ancaman bagi dirinya untuk kemudian dapat mengoptimalkan sumberdaya yang tersedia untuk memajukan sekolah.

b. Sekolah dapat mengembangkan sendiri program-program sesuai dengan kebutuhannya.

c. Sekolah dapat bertanggung jawab tentang mutu pendidikan masingmasing kepada orang tua, masyarakat, dan pemerintah serta;

d. Sekolah dapat melakukan persaingan sehat dengan sekolah lain untuk meningkatkan mutu pendidikan. ${ }^{24}$

\section{Karakteristik Manajemen Berbasis Sekolah}

Karakteristik MBS bisa diketahui antara lain dari berbagai sekolah dapat mengoptimalkan kinerja organisasi sekolah, proses pembelajaran. Pengelolaan sumber daya manusia, dan pengelolaan sumber daya dan administrasi. Menurut Tim Teknis Badan Perencanaan Pembangunan Nasional (BPPN) bekerjasama dengan Bank Dunia (1999), karakteristik manajemen berbasis sekolah dirumuskan sebagai berikut:

\footnotetext{
${ }^{23}$ Umaedi, Managemen Peningkatan Mutu Berbasis Sekolah, h. 4

${ }^{24}$ Ibrahim Bafadal, Manajemen Peningkatan Mutu Sekolah Dasar, dari Sentralisasi Menuju Desentralisasi, h. 84
} 
a. Pengoptimalan kinerja organisasi sekolah meliputi:

- Menyediakan manajemen organisasi transformasional dalam mencapai tujuan sekolah

- Menyusun rencana sekolah dan merumuskan kebijakan untuk sekolahnya sendiri

- Mengelola kegiatan operasional sendiri

- Menjamin adanya komunikasi yang efektif antar sekolah dan masyarakat terkait (School Community)

- Menjamin akan terpeliharanya sekolah yang bertanggung jawab (accountability) kepada masyarakat dan pemerintah.

b. Pengoptimalan proses pembelajaran meliputi:

- Meningkatkan kualitas belajar peserta didik

- Mengembangkan kurikulum yang cocok dan tanggap terhadap kebutuhan peserta didik dan masyarakat sekolah

- Menyelenggarakan pengajaran yang efektif

- Menyediakan program pengembangan yang diperlukan peserta didik

- Program pengembangan yang diperlukan peserta didik.

c. Pengoptimalan sumberdaya manusia meliputi:

- Memberdayakan staf dan menempatkan personal yang dapat melayani keperluan semua peserta didik

- Memilih staf yang memiliki wawasan manajemen berbasis sekolah

- Menyediakan kegiatan untuk pengembangan profesi pada semua staf

- Menjamin kesejahteraan staf dan peserta didik

d. Pengoptimalan sumberdaya dan administrasi meliputi:

- Mengidentifikasi sumberdaya yang diperlukan dan mengalokasikan sumberdaya tersebut sesuai dengan kebutuhan

- Mengelola dana sekolah

- Menyediakan dukungan administratif dan mengelola

- Memelihara gedung dan sarana lainnya. ${ }^{25}$

Melalui penerapan Manajemen Berbasis Sekolah akan nampak karakteristik lainnya dari profil sekolah mandiri, diantaranya sebagai berikut:

1. Pengelolaan sekolah akan lebih desentralistik

2. Perubahan sekolah akan lebih didorong oleh motivasi internal daripada diatur oleh luar sekolah

3. Regulasi pendidikan lebih sederhana

4. Peranan para pengawas bergeser dari mengontrol jadi mempengaruhi, dari mengarahkan menjadi menfasilitasi dan dari menghindari resiko menjadi mengelola resiko

5. Akan mengalami peningkatan manajemen

\footnotetext{
${ }^{25}$ E. Mulyasa, Manajemen Berbasis Sekolah, Konsep, Strategi dan Implementasi, (Bandung: PT Rosda karya, 2002), h. 29-30
} 
6. Dalam bekerja, akan menggunakan tim work

7. Pengelolaan informasi akan lebih mengarah kesemua kelompok kepentingan sekolah

8. Manajemen sekolah akan lebih menggunakan pemberdayaan dan struktur organisasi akan lebih datar sehingga akan lebih sederhana dan efisien. ${ }^{26}$

\section{Langkah-Langkah Peningkatan Pembelajaran Bahasa Arab Dengan Penerapan Manajemen Berbasis}

Dalam rangka peningkatan pembelajaran bahasa Arab yang berbasis manajemen berbasis sekolah, maka perlu dilakukan pendekatan sistem dalam manajemennya. Pendekatan sistem tersebut mencakup tiga aspek, yaitu aspek input, proses, dan out put.

1). Ditinjau dari segi input

a. Tenaga kependidikan

Tenaga pendidikan merupakan urat nadi keberhasilan pembelajaran, karena itu seorang guru yang memiliki kemampuan untuk mempertanggungjawabkan materi yang diampunya, khususnya bahasa Arab. Guru inilah yang senantiasa ditekankan agar mengasah diri untuk lebih menajamkan keilmuannya dalam bidang bahasa Arab. Kepala madrasah juga memberikan kesempatan yang seluas-luasnya untuk menentukan buku pegangan pokok atau referensi bagi guru maksimal 5 buah buku yang dibiayai dari anggaran sekolah.

Untuk memastikan seorang guru sudah mengetahui bahan dan konsep keilmuan, maka perlu dilakukan supervisi kelas minimal 1 kali dalam satu semester.

b. Pemanfaatan fasilitas secara efesien dan efektif

Selanjutnya, hal-hal yang berkaitan dengan upaya yang dilakukan untuk meningkatkan pembelajaran bahasa Arab adalah melakukan manajemen pengelolaan sarpras secara tertib dan baik secara efektif dan efesien, terutama yang berkaitan dengan penyelenggaraan pembelajaran, khsusnya bahasa Arab. Di samping itu pula pengelolaan fasilitas/sarana dan keuangan yang ada diupayakan dengan:

a) Meningkatkan pelayanan perpustakaan dan pengadaan buku

b) Mengidentifikasi buku-buku, baik berkerjasama dengan instansi terkait maupun membeli sendiri dengan dana yang tersedia.

c) Bila memungkinkan mengadakan pelatihan bagi tenaga perpustakaan

d) Menambah saranan dan prasarana penunjang KBM berupa penggantian papan tulis hitam menjadi white board, menambah alat bantu peraga, dan lain-lain yang diusulkan oleh guru mata pelajaran.

e) Pengembangan standar isi (kurikulum)

Dalam melaksanakan pelaksanaan urusan kurikulum, agar kurikulum yang dipergunakan di sekolah khususnya Bahasa Arab selalu up to date, sehingga siswa dapat mencapai standar yang telah ditetapkan. Beberapa langkah yang dilakukan adalah:

\footnotetext{
${ }^{26} \mathrm{http} / /$ www.depdiknas.go.id/file: //A :MANAJEMEN PENDIDIKAN MASA DEPAN.htm
} 
(1)Membuat dan menyempurnakan kurikulum (silabus, RPP, dan KKM) secara terus menerus agar kurikulum dapat sesuai dengan tuntutan relevansi.

(2)Mengikuti pelatihan dan penataran kurikulum baik di tingkat lembaga pendidikan di lingkungan Kemenag dan yayasan maupun tingkat kota.

(3)Melaksanakan workshop untuk meningkatkan kemampuan guru.

(4)Melaksanakan dan mengembangkan Kurikulum secara otonom dengan semangat manajamen berbasis sekolah untuk semua mata pelajaran.

(5) Mengembangkan pengembangan standar proses pendidikan.

(6)Melaksanakan workshop pengembangan metode pembelajaran

(7)Melaksanakan workshop strategi pembelajaran

(8)Melaksanakan program intrakurikuler yang meliputi :

a. Menganalisis soal-soal Ujian Nasional

b. Pengorganisasian program belajar mengajar

c. Pengembangan dan penguasaan bahan dan program pengajaran

(9)Melaksanakan program kegiatan ekstrakurikuler.

Namun manakala kurikulum tidak memberikan ruang pada guru untuk melakukan inovasi dalam mengembangkan pembelajaran, maka dapat dipastikan pembelajaran yang dilakukannya akan mengalami stagnasi. Tetapi sebaliknya, apabila kurikulum dikembangkan dengan ekastisitas yang tinggi untuk memberikan ruang gerak kepada pendidik untuk melakukan pengembangan pembelajarannya, maka guru dapat leluasa untuk mengejar ketercapaian kompetensi yang dituntut pada suatu topik pembelajaran.

Jadi, dapat dipahami bahwa regulasi kurikulum yang ada dapat memberikan ruang gerak yang lebih leluasa oleh guru, khususnya guru bahasa Arab untuk lebih mengembangkan program pembelajarannya. Kebijakan ini merupakan pengejawantahan pengelolaan sekolah yang mandiri dalam melakukan rencana-rencana pengembangan ke arah yang lebih baik, khsusunya dalam menunjang ketercapaian kompetensi siswa dalam proses pembelajaran bahasa Arab.

(d) Keuangan

Untuk menjamin keterlaksanaan semua program sekolah, sangat memberikan perhatian dalam hal tata kelola keuangan. Penyebabnya adalah untuk melaksanakan semua program membutuhkan anggaran. Oleh karena itu dalam mengelola anggaran, selalu menghadirkan semua guru dan staf termasuk komite sekolah untuk membicarakan pengelolaan keuangan agar dapat mengalokasikan anggaran pada aspek-aspek yang memiliki urgensi yang tinggi, sehingga program yang dapat menunjang kualitas dapat dikedepankan.

2). Ditinjau dari segi proses

\section{a. Proses KBM}

Kegiatan pembelajaran memegang peranan penting sekali di dalam sekolah. Oleh karena itu, guru harus betul-betul mempersiapkan dan merancang dengan baik kegiatan pembelajaran ini, sehingga dengan persiapan yang baik diharapkan kualitas pembelajaran akan semakin lebih baik. Sehubungan dengan hal tersebut, maka guru bahasa Arab mengemukakan bahwa kegiatan pembelajaran yang dilakukan memaksimalkan pemanfaatan 
sarana dan prasarana yang ada dalam menunjang pembelajaran. Sebelum pelaksanaan pembelajaran senantiasa melakukan di antaranya:

1) Membuat Program Tahunan (Prota)

2) Program Semester (Promes)

3) Membuat Rencana Persiapan Pembelajaran (RPP)

4) Membuat analisis materi pelajaran

Selain itu, untuk menunjang pencapaian kompetensi yang harus dicapai oleh peserta didik, diperlukan juga memberikan pelajaran tambahan, baik dalam bentuk les atau kegiatankegiatan lain yang dapat mempercepat penguasan bahasa Arab mereka. Kegiatan-kegiatan itu menekankan agar mereka mampu melakukan percakapan kecil atau kegiatan lain yang menggunakan bahasa Arab. Kegiatan ini sekolah telah memberikan ruang gerak untuk mengembangkan program pembelajaran.

\section{3) Ditinjau dari Out put}

Out put atau hasil yang dicapai dari keseluruhan proses MBS dalam upaya meningkatkan pembelajaran bahasa Arab selalu diukur berdasarkan ketercapaian kompetensi yang harus dimiliki oleh peserta didik setelah mengikuti pembelajaran. Dengan kata lain seluruh proses yang pengelolaan pembelajaran yang berbasis MBS khususnya pada mata pelajaran bahasa Arab bermuara kepada pencapaian kompetensi peserta didik yang telah tertuang pada kurikulum bahasa Arab secara nasional.

Adapun kompetensi yang harus dicapai oleh siswa sebagai hasil (out put) pembelajaan bahasa Arab adalah:

a.Peserta didik mampu mendengarkan, berbicara, membaca, dan menulis secara baik.

b.Peserta didik mampu berbicara secara sederhana tapi efektif dalam berbagai konteks untuk menyampaikan informasi, pikiran dan perasaan, serta menjalin hubungan sosial dalam bentuk kegiatan yang beragam, interaktif dan menyenangkan.

c.Peserta didik mampu menulis kreatif meskipun pendek dan sederhana.

d.Peserta didik mampu menghayati dan menghargai karya sastra.

e.Peserta didik mampu menganalisis teks secara kritis.

f. Peserta didik memiliki perbendaharaan kata 700, kata Arab fusha dalam berbagai bentuk kata dan pola kalimat.

\section{E. Penutup}

Dalam pembelajaran harus ada upaya-upaya agar motivasi yang sudah ada pada diri pembelajaran tetap terpelihara dan ditingkatkan karena motivasi berguna untuk menghubungkan pengalaman yang lama dengan bahan pelajaran yang baru, sebab setiap peserta didik datang ke kelas dengan latar belakang yang berbeda-beda. Dengan motivasi, peserta didik mengalami dalam belajar dan merasa terdorong untuk mempelajari bahanbahan baru.

a. Bahan ajar

b. Alat bantu ajar

c. Suasana belajar 
d. Kondisi subyek yang belajar

Seperti yang tercantum dalam UU Nasional No. 20 tahun 2003, yang menyatakan bahwa pendidikan nasional berfungsi untuk mengembangkan kemampuan dan pengembangan karakter dan peradaban bangsa dalam meningkatkan kehidupan intelektual bangsa, bertujuan untuk mengembangkan potensi peserta didik untuk menjadi manusia dengan keimanan dan ketaqwaan kepada Tuhan yang Maha Esa, berakhlaq mulia, sehat, berilmu, cakap, kreatif, mandidiri, dan menjadi warga negara yang demokratis dan bertanggungjawab. Untuk mencapai tujuan pendidikan nasional tersebut, maka tidak ada upaya yang dapat dilakukan melainkan memberikan pelayanan pendidikan yang terbaik kepada peserta.

\section{F. Daftar Pustaka}

E.Mulyasa. Menjadi Guru Profesional Menciptakan Pembelajaran Kreatif dan Menyenangkan. (Bandung: Rosakarya, Cet. VII, 2008)

Manajemen Berbasis Sekolah, Konsep, Strategi dan Implementasi, (Bandung: PT Rosda karya, 2002)

Manajemen Pendidikan Karakter. (Jakarta: Bumi Aksara, 2012)

Sudarwan Danim. Menjadi Komunitas Pembelajaran. (Jakarta: Bumi Aksara, 2005)

Pemerintah Republik Indonesia. Undang-Undang Dasar Negara RI Tahun 1945, pasal 31 ayat (4)

Kementerian Agama RI. Pedoman Khusus Bahasa Arab Madrasah Tsanawiyah. (Jakarta: Dirjen Kelembagaan Agama Islam Depag RI, 2004)

Muhibbin Syah. Psikologi Pendidikan. (Bandung: PT. Remaja Rosdakarya, 2000)

Pemerintah Republik Indonesia. Undang-Undang Sistem Pendidikan Nasional. No. 20 Tahun 2003. (Jakarta: Sinar Grafika, 2009)

Oemar Hamalik. Kurikulum dan Pembelajaran. (Jakarta: Bumi Aksara, 2007)

John M.Echols dan Hassan Shadily. Kamus Inggris Indonesia. (Jakarta: PT. Gramedia, 2006)

Ahmad Maulana, dkk. Kamus Ilmiah Populer. (Yogyakarta: Absolut, 2004)

Peraturan Menteri Agama No. 2 Tahun 2008, Bab VI.

Permenag No 2 Tahun 2008, BAB I, Tentang Standar Kompetensi Lulusan Mata Pelajaran Pendidikan Agama Islam dan Bahasa Arab Madrasah Ibtidaiyah.

Furqonul Aziz dan Chaidar Al-Wasilah. Pengajaran Bahasa Komunikatif. (Bandung: Remaja Rosda Karya, 2000, Cet. II) 
Sudarwan Danim. Visi Baru Manajemen Sekolah, Dari Unit Birokrasi Ke Lembaga Akademik.

Jamal Ma’mur Asmani. Tips Aplikasi Manajemen Sekolah. (DIVA press, anggota IKAPI, 2012)

Kementerian Pendidikan Nasional. Paket Pelatihan 1, peningkatan mutu pendidikan dasar melalui manajemen berbasis sekolah, peran serta masyarakat, pembelajaran aktif, kreatif, efektif dan menyenangkan, Juni 2005

Umaedi. Managemen Peningkatan Mutu Berbasis Sekolah. (Jakarta: Kementerian Pendidikan Nasional Direktorat Jendral Pendidikan Dasar dan Menengah Direktorat Sekolah Lanjutan Tingkat Pertama

Eddy Warsono dan Karsidi Budi Anggoro. Otonomi Pendidikan di Era Otonomi Daerah

Ibrahim Bafadal. Manajemen Peningkatan Mutu Sekolah Dasar, dari Sentralisasi Menuju Desentralisasi. Jakarta: Bumi Aksara, 2003.

http// www.depdiknas.go.id/file: //A :MANAJEMEN PENDIDIKAN MASA DEPAN.htm 